\title{
Lysis Test of Ascaris lumbricoides Eggs After Giving Ethanol Extract of Chinese Ketepeng Leaves (Cassia alata L.)
}

\author{
Sri Kartini ${ }^{1}$, Ira Oktaviani. RZ ${ }^{2}$, Amira Dian Destari ${ }^{1}$ \\ Universitas Abdurrab', Poltekkes Kemenkes Riau² \\ sri.kartini@univrab.ac.id
}

\section{Article Info}

Article history

Received date: 1 1-25-2020

Revised date: 12-14-2020

Accepted date: $01-11-2020$

\begin{abstract}
Helminthiasis is an environmet based disease, which can be transmitted throuht the soil or known as soil transmitted helminth (STH). Infection caused by these parasites can be eradicated by giving synthetic drugs and herbal medicines. One of the plants that can be used as herbal medicine is ketepeng cina (Cassia alata L.). chinese ketepeng leaves (Cassia alata L.) have one benefit, namely to treat intestinal worms. This study aims to determine the morphological changes of eggs Ascaris lumbricoides after the administration of ethanol extract of chinese ketepeng leaves (Cassia alata L.) with concentration 1\%, 2\%, 3\%, 4\%, 5\%. The method used in this study is laboratory experiments. The results of this study indicate that the ethanol extract of chinese ketepeng leaves (Cassia alata L.) in concentrated $4 \%$ and $5 \%$ changes color in the eggs but there is no morphological change in eggs. From this study it can be concluded that the ethanol extract of chinese ketepeng leaves (Cassia alata L.) is not able to damage the morphologi of Ascaris lumbricoides worm eggs.
\end{abstract}

Keywords:

Lysis test, Eggs Ascaris lumbricoides, Ketepeng cina

\begin{abstract}
Abstrak
Infeksi cacingan merupakan penyakit yang berbasis lingkungan, dapat ditularkan melalui tanah atau dikenal dengan soil transmitted helminth (STH). Infeksi yang disebabkan oleh parasit ini dapat diberantas dengan pemberian obat sintesis dan obat herbal. Salah satu tanaman yang bisa digunakan sebagai obat herbal adalah ketepeng cina (Cassia alata L.). Daun ketepeng cina (Cassia alata L.) memiliki salah satu manfaat yaitu untuk mengatasi cacingan. Penelitian ini bertujuan untuk mengetahui perubahan morfologi telur Ascaris lumbricoides setelah pemberian ekstrak etanol daun ketepeng cina (Cassia alata L.) dengan konsentrasi 1\%,2\%,3\%, 4\%, 5\%. Metode yang digunakan dalam penelitian ini adalah eksperimen laboratorium. Hasil dari penelitian ini menunjukkan bahwa ekstrak etanol daun ketepeng cina (Cassia alata L.) pada konsentrasi $4 \%$ dan $5 \%$ terjadi perubahan warna pada telur tetapi tidak terjadi perubahan morfologi pada telur. Dari penelitian ini dapat disimpulkan bahwa ekstrak etanol daun ketepeng cina (Cassia alata L.) pada konsentrasi di atas tidak mampu merusak morfologi telur cacing Ascaris lumbricoides.
\end{abstract}

Kata Kunci

Uji lisis; Telur Ascaris lumbricoides; Ketepeng cina

\section{PENDAHULUAN}

Kecacingan merupakan salah satu penyakit yang berbasis pada lingkungan yang beriklim tropis dan subtropis. Menurut data WHO (2020), lebih dari 1,5 miliar orang, atau $24 \%$ dari populasi dunia, terinfeksi infeksi cacing soil transminth helmint (STH) yang ditularkan melalui tanah di seluruh dunia [1]. Lebih dari 267 juta anak usia prasekolah dan lebih dari 568 juta anak usia sekolah tinggal di daerah di mana 
parasit ini ditularkan secara intensif, dan membutuhkan pengobatan dan intervensi pencegahan. Salah satu caacing STH yang menginfeksi adalah jenis Acaris lubricoides. Ascariasis ditemukan di seluruh dunia merupakan infeksi yang paling umum. Infeksi terjadi di daerah dengan sanitasi yang tidak memadai. Hingga 10\% populasi negara berkembang terinfeksi cacingan sebagian besar disebabkan oleh Ascaris. Di seluruh dunia, infeksi Ascaris yang parah menyebabkan sekitar 60.000 kematian per tahun, terutama pada anak-anak [2].

Pemberantasan infeksi cacingan hingga kini terus dilakukan dengan pemberian obat sintesis. Obat cacing yang paling banyak digunakan diantaranya: albendazol, mebendazol dan pirantel pamoat (Kementrian Kesehatan RI, 2012). Obat-obatan sintesis memiliki efek samping terhadap masingmasing individu penggunanya. Efek samping yang ditimbulkan oleh obat mebendazol adalah mual ringan, diare, nyeri perut, gatal, kulit kemerahan, eosinofilia, demam, fungsi hati abnormal [3]. Pemakaian jangka lama juga tidalk baik bagi kesehatan. Usaha untuk memanfaatkan bahan alam dalam pemberantasan kecacingan telah banyak dilakukan. Tanaman yang banyak digunakan salah satunya ketepeng cina ( $C$. alata L) Penelitian terdahulu tentang kandungan kimia daun ketepeng cina pada daun segar menunjukkan adanya alkaloid, steroid, terpenoid, saponin, flavonoid, fenolik dan dan tanin. Sedangkan pada daun kering menunjukkan adanya alkaloid, fenol dan tanin $[4,5]$.

Beberapa penelitian efektifitas anthalmitik daun ketepeng adalah terhadap ascaris suum $[6 ; 7 ; 8 ; 9]$. Kemampuan ekstrak daun ketepeng cina untuk membunuh cacing Ascaris suum disebabkan karena adanya senyawa aktif tertentu berupa alkaloid, saponin, tanin, steroid, antrakuinon, dan flavonoid. Senyawa saponin mempunyai efek menurunkan tegangan permukaan pada dinding membran, dan menghambat kerja enzim asetilkolinesterase yang menyebabkan paralisis spastik otot [5]. Saponin merupakan glikosida mempunyai rasa pahit dan dapat menurunkan tegangan permukaan dinding membran [10]. Senyawa saponin mempunyai efek menghambat kerja enzim khemotripsin, asetilkolinesterase dan preoteinase. Menurut Iman (2016), senyawa aktif saponin yang menghambat kerja asetilkolinesterase menyebabkan paralisis spastik otot mengakibatkan kematian pada cacing Ascaris suum [7].

Tanin juga memiliki daya anthalmitik. Tanin umumnya berasal dari senyawa polifenol yang memiliki kemampuan untuk mengendapkan protein dengan membentuk koopolimer yang tidak larut dalam air [1 1]. Tanin juga memiliki aktivitas ovisidal, yang dapat mengikat telur cacing yang lapisan luarnya terdiri atas protein sehingga pembelahan sel di dalam telur tidak akan berlangsung pada akhirnya larva tidak terbentuk. Sesuai dengan Molan et al. (2000) [12]. Hasil penelitian Tiwon (2013) [13] bahwa Ekstrak etanol biji pinang pada konsentrasi $30 \%$ lebih efektif daya anthalmitiknya terhadap cacing Ascaris lumbricoides dan cacing Ascaridia galli, Senyawa tanin akan melisiskan dinding telur terluar yang mengandung albumin dengan cara mengendapkan protein.

Penelitian yang dilakukan oleh Iman, dkk (2015) [7] dalam uji mortalitas cacing Ascaris suum menggunakan ekstrak daun ketepeng cina dengan konsentrasi $20 \%$, $40 \%$, 60\%, dan $80 \%$ dimana pengaruh konsentrasi berinteraksi positif dengan pengaruh waktu terhadap mortalitas cacing Ascaris suum, penelitian oleh Agung (2014) menggunakan konsentrasi 1,5\%,3\%, 4,5\%, $6 \%$ ekstrak daun pepaya. Belum ada penelitian tentang efek anthalmentik ekstrak daun kepetepeng terhadap telur cacing 
ascaris lumbriocoides. Penelitian ini menggunakan ektrak etanol pada konsentrasi $1,5 \%, 3 \%, 4,5 \%, 6 \%$.

\section{METODE}

\section{Desaian Penelitian}

Penelitian ini adalah eksperimen laboratorium secara invitro dengan adanya perlakuan yang diberikan pada obyek penelitian dengan pemberian ekstrak daun ketepeng cina dengan konsentrasi $1 \%, 2 \%$, $3 \%, 4 \%, 5 \%$ terhadap telur ascaris lumbriocoides. Sampel berupa telur Ascaris lumbricoides, yang diperoleh dari suspensi feses segar yang positif telur Ascaris lumbricoides. Penelitian dilaksanakan di Laboratorium Parasitologi Universitas Abdurrab dan FMIPA Universitas Riau pada Juli 2019. Data hasil berupa skrining fitokimia dan pengamatan perubahan morfologi pada telur ascaris pada berbagai konsentrasi, data disajikan dalam bentuk tabel dan gambar.

Ekstraksi daun ketepeng cina (Cassia alata L.)

ditimbang sebanyak $1,5 \mathrm{~kg}$ daun ketepeng cina, lalu dicuci dan ditiriskan, dirajang kecilkecil, kemudian dikeringkan dengan cara diangin-anginkan. Setelah kering dihaluskan menjadi serbuk. Sebanyak $300 \mathrm{~g}$ serbuk direndam dengan metanol $70 \%$ sampai terendam semua (volume etanol $\pm 2 \mathrm{~L}$ ). Setelah itu sampel didiamkan selama $3 \times 24$ jam dengan sesekali diaduk. Selanjutnya sampel disaring menggunakan kertas saring dan didapatkan ekstrak cair.

Ekstrak cair dievaporasi menggunakan alat rotary evaporator sampai sedikit mengental, kemudian sampel diuapkan di atas waterbath suhu $50^{\circ} \mathrm{C}$ untuk mendapatkan ekstrak yang lebih pekat.

\section{Pengujian lisis telur cacing Ascaris lumbricoides terhadap ekstrak daun ketepeng cina (Cassia alata L.)}

Pengujian menggunakan ekstrak daun ketepeng cina dengan variasi konsentrasi $1 \%, 2 \%, 3 \%, 4 \%, 5 \%$, terlebih dahulu sediakan plat tetes, tambahkan 10 tetes konsentrasi ekstrak ke plat tetes, kemudian tambahkan 2 tetes suspensi sampel dan lakukan pengujian dengan waktu 15 menit, 30 menit, 45 menit, dan 60 menit. Lakukan hal yang sama pada konsentrasi ekstrak $1 \%, 2 \%, 3 \%, 4 \%, 5 \%$. Selanjutnya siapkan kaca objek dengan diberi label, kemudian teteskan 1 tetes campuran konsentrasi ekstrak dan suspensi di atas kaca objek dan ditutup dengan kaca penutup. Amati sediaan di mikroskop dengan lensa objektif $10 x$ dan 40x. Terjadinya lisis pada telur Ascaris lumbricoides ditandai dengan adanya perubahan morfologi pada telur setelah pemberian ekstrak daun ketepeng cina (Cassia alata L.) pada konsentrasi tertentu [14].

\section{HASIL DAN PEMBAHASAN}

Ekstrak daun ketepeng cina (Cassia alata $L$.) Pada proses maserasi, serbuk daun ketepeng cina ditimbang $300 \mathrm{~g}$ dan direndam dengan pelarut etanol $70 \%$ (volume etanol $\pm 2 \mathrm{~L}$ ) selama $3 \times 24$ jam dengan sesekali diaduk, setelah itu disaring menggunakan kertas saring.

Setelah proses maserasi didapatkan ekstrak cair yang berwarna hijau pekat dan memiliki aroma yang khas. Selanjutnya ekstrak cair dievaporasi menggunakan alat rotary evaporator dan diperoleh ekstrak kental sebanyak $40 \mathrm{~g}$.

Hasil Pengujian fitokimia

Hasil uji fitokimia ekstrak daun ketepeng cina dapat dilihat pada tabel 1 dibawah ini. 
Tabel 1. Hasil Uji Fitokimia Identifikasi Senyawa Dari Ekstrak Daun Ketepeng Cina (Cassia alata L.)

\begin{tabular}{|c|c|c|c|c|}
\hline No & $\begin{array}{c}\text { Senyawa } \\
\text { Uji }\end{array}$ & Pereaksi & Hasil & Reaksi \\
\hline 1 & Flavonoid & $\begin{array}{c}\text { Etanol } 70 \% \\
\mathrm{HCl} \text { Pekat } \\
\text { Magnesium }\end{array}$ & $\begin{array}{l}\text { Positif } \\
(+)\end{array}$ & $\begin{array}{l}\text { Terbentuk } \\
\text { warna } \\
\text { jingga }\end{array}$ \\
\hline 2 & Tanin & $\mathrm{FeCl}_{3}$ & $\begin{array}{l}\text { Positif } \\
(+)\end{array}$ & $\begin{array}{l}\text { Terbentuk } \\
\text { warna hijau } \\
\text { kehitaman }\end{array}$ \\
\hline 3 & Saponin & $\mathrm{HCl} 2 \mathrm{~N}$ & $\begin{array}{l}\text { Positif } \\
(+)\end{array}$ & $\begin{array}{c}\text { Terbentuk } \\
\text { busa }\end{array}$ \\
\hline 4 & Alkaloid & $\begin{array}{c}\mathrm{HCl} 2 \mathrm{~N} \\
\text { Akuades } \\
\text { Mayer }\end{array}$ & $\begin{array}{l}\text { Positif } \\
(+)\end{array}$ & $\begin{array}{c}\text { Terbentuk } \\
\text { endapan } \\
\text { putih }\end{array}$ \\
\hline
\end{tabular}

Perlakuan ekstrak terhadap telur cacing Ascaris lumbricoides dapat dilihat pada tabel dibawah ini:

Tabel 2. Hasil Pengamatan Perubahan Morfologi Telur Ascaris Lumbricoides Setelah Pemberian Ekstrak

\begin{tabular}{ccccc}
\hline \multirow{2}{*}{$\begin{array}{c}\text { Variasi } \\
\text { konsentrasi } \\
\text { uji }\end{array}$} & \multicolumn{4}{c}{ Waktu Uji } \\
\cline { 2 - 5 } & $\begin{array}{c}\mathbf{1 5} \\
\text { menit }\end{array}$ & $\begin{array}{c}\mathbf{3 0} \text { menit } \\
\text { masil Uji }\end{array}$ & $\begin{array}{c}\mathbf{4 5} \\
\text { menit }\end{array}$ & $\mathbf{6 0}$ menit \\
\hline $\begin{array}{c}\text { Konsentrasi } \\
1 \%\end{array}$ & TTPM & TTPM & TTPM & TTPM \\
& TTPW & TTPW & TTPW & TTPW \\
Konsentrasi & TTPM & TTPM & TTPM & TTPM \\
$2 \%$ & TTPW & TTPW & TTPW & TTPW \\
& & & & \\
Konsentrasi & TTPM & TTPM & TTPM & TTPM \\
$3 \%$ & TTPW & TTPW & TTPW & TTPW \\
Konsentrasi & TTPM & TTPM & TTPM & TTPM \\
$4 \%$ & TTPW & TTPW & TTPW & WTSM \\
& & & & \\
Konsentrasi & TTPM & TTPM & TTPM & TTPM \\
$5 \%$ & TTPW & TPWT & WTSM & WTMP \\
& & & &
\end{tabular}

Ket:

TTPM : Tidak Terjadi Perubahan Morfologi TPPW: Tidak Terjadi Perubahan Warna WTSM: Warna pada Telur Sedikit Memudar TPWT: Terjadi Perubahan Warna pada Telur WTMP: Warna pada Telur Menjadi Pudar

\section{Pembahasan}

Setelah dilakukan pengujian ekstrak daun ketepeng cina (Cassia alata L.) dengan konsentrasi $1 \%, 2 \%, 3 \%, 4 \%, 5 \%$ terhadap telur cacing Ascaris lumbricoides, hasil menunjukkan pada konsentrasi $4 \%$ dan $5 \%$ terjadi perubahan warna pada telur tetapi tidak terjadi perubahan morfologi pada telur. Sedangkan pada konsentrasi $1 \%, 2 \%$, dan $3 \%$ hasil yang didapat yaitu tidak ada perubahan pada morfologi dan warna pada telur. Hasil uji fitokimia menunjukkan ekstrak daun ketepeng cina yang digunakan dalam penelitian ini positif memiliki senyawa-senyawa yang berpotensi melisiskan morfologi telur cacing Ascaris lumbricoides.

Daya antihelmintik pirantel pamoat (Combatrin cair $125 \mathrm{mg}$ ) digunakan sebagai kontrol positif karena sudah sering digunakan dalam memberantas cacing gelang, cacing kremi dan cacing tambang. Pirantel pamoat dapat membunuh cacing dengan cara merusak subseluler dan menghambat glukosa sehingga terjadi deplesi glikogen pada cacing [7].

Menurut Musa (2014) daun ketepeng cina mempunyai kelebihan seperti daya antihelmintik berdasarkan senyawa aktif seperti tanin, flavonoid dan saponin. Kehadiran tanin yang tinggi pada daun ketepeng cina menyebabkan terikatnya enzim-enzim yang dihasilkan oleh cacing Ascaris lumbricoides untuk penyerapan nutrisi sehingga penyerapan terganggu. Selain tanin, zat aktif seperti flavonoid yang menyebabkan denaturasi protein dalam jaringan cacing sehingga menyebabkan kematian cacing [15]. 
Vol.9, No.2, November 2020, pp. 9-15

ISSN 2580-0191 (Online), ISSN 2338 - 5634 (Print)

Tabel 2. Hasil Pengujian Ekstrak Etanol Daun Ketepeng Cina (Cassia alata L.) terhadap

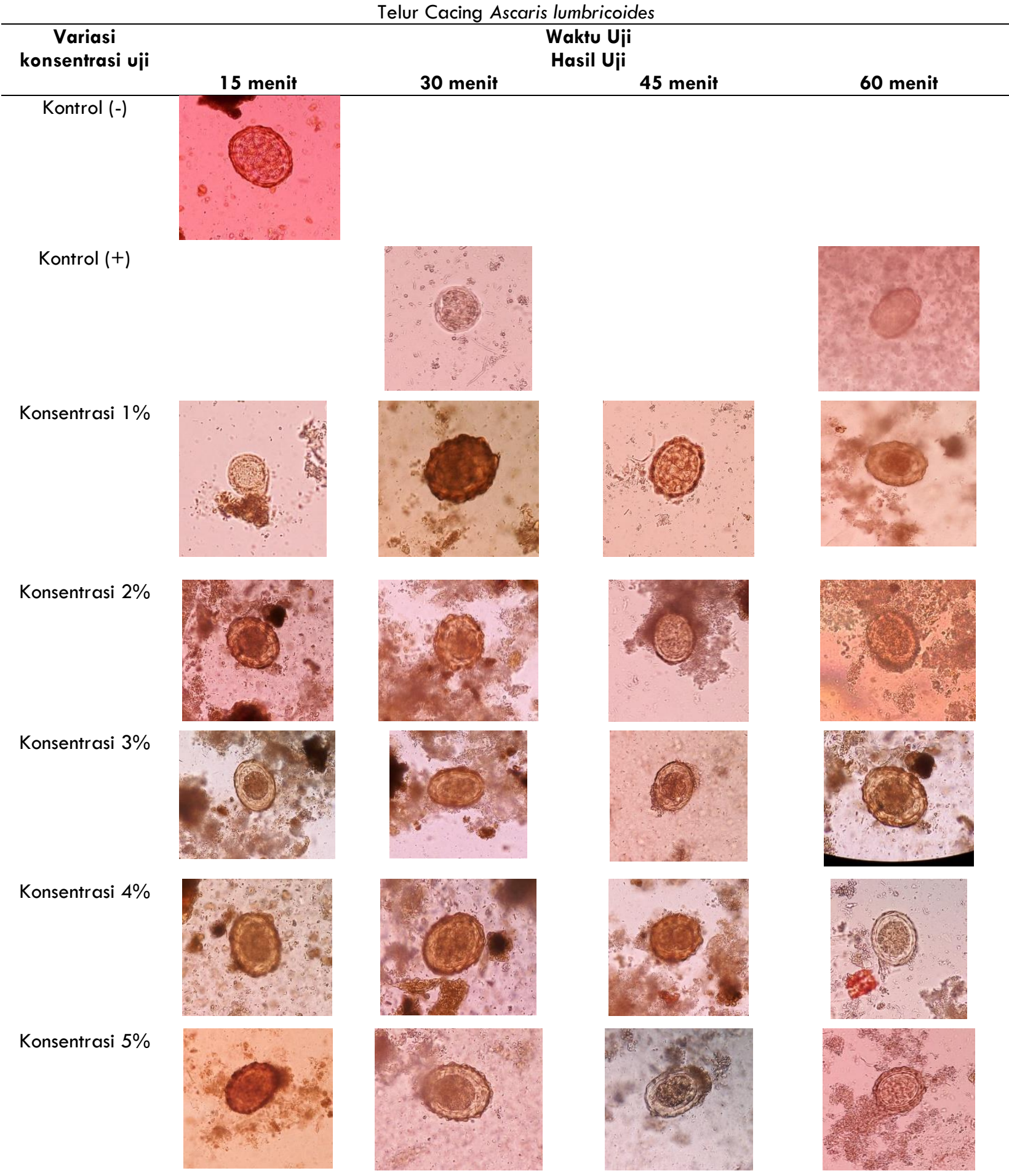


Pada penelitian yang dilakukan oleh Iman (2015) daun ketepeng cina berfungsi sebagai antihelmintik disebabkan karena adanya senyawa aktif tertentu berupa alkaloid, saponin, tanin, steroid, antrakuinon, dan flavonoid. Senyawa saponin mempunyai efek menurunkan tegangan permukaan pada dinding membran, dan menghambat kerja enzim asetilkolinesterase yang menyebabkan paralisis spastik otot yang akhirnya menimbulkan kematian pada cacing Ascaris suum [7].

Pada penelitian yang dilakukan oleh Bora (2014) menggunakan daun pepaya untuk daya lisis telur dan cacing Ascaris suum dengan konsentrasi $1,5 \%, 3 \%, 4,5 \%$, dan $6 \%$ didapatkan hasil yaitu terjadinya lisis pada telur cacing Ascaris suum [16].

Perubahan warna telur yang terjadi pada konsentrasi $4 \%$ dan $5 \%$, disebabkan oleh adanya kandungan senyawa tanin pada ekstrak daun ketepeng cina (Cassia alata L.). Menurut Soedarto (2016), telur Ascaris lumbricoides berwarna coklat karena menyerap zat warna cairan empedu yang bersifat basa [17]. Musa (2014) mengatakan bahwa senyawa fenol dari tanin memiliki beberapa aksi berupa adstrigensia, antiseptik, dan aksi pemberi warna, selain itu tanin juga memiliki $\mathrm{pH}$ yang asam sehingga dapat mengakibatkan perubahan warna pada telur. Apabila dilihat dari perubahan warna yang baru mulai terjadi pada konsentrasi $3 \%$ dan 5\%, kemungkinan jika konsentrasi ditingkatkan maka ekstrak etanol daun ketepeng mampu melisiskan telur ascarias lumbricoides [15]. Seperti pada penelitian Iman (2015) menggunakan konsentrasi $80 \%$ ekstrak daun ketepeng untuk melisiskan telur ascaris suum dan pada penelitian Tiwon (2013) pada konsentrasi $30 \%$ ekstrak biji pinang mampu melisiskan telur ascaris lumbricoides $[7 ; 13]$. Telur Ascaris lumbricoides memiliki tiga lapisan yaitu bagian luar terdiri dari lapisan albumin yang permukaannya bergerigi, sedangkan lapisan dalam terdiri dari hialin dan vitelin yang tipis tetapi kuat sehingga telur dapat bertahan sampai satu tahun di dalam tanah [17]. Lapisan hialin dan vitelin yang cukup kuat ini memungkinkan konsentrasi ekstrak etanol daun ketepeng tidak mampu melilisiskan telur ascaris lumbricoides.

\section{SIMPULAN}

Berdasarkan hasil penelitian tentang Uji Lisis Telur Cacing Ascaris lumbricoides Setelah Pemberian Ekstrak Etanol Daun Ketepeng Cina (Cassia alata L.) dapat disimpulkan: Ekstrak daun ketepeng cina (Cassia alata L.) dengan konsentrasi $1 \%, 2 \%, 3 \%, 4 \%, 5 \%$ tidak dapat merusak morfologi telur cacing Ascaris lumbricoides, tetapi pada konsentrasi $4 \%$ dan $5 \%$ terjadi perubahan warna pada telur. Ekstrak daun ketepeng cina (Cassia alata L.) memiliki senyawa metabolit sekunder yaitu flavonoid, tanin, saponin, dan alkaloid.

\section{DAFTAR PUSTAKA}

[1] WHO. (2020). Soil-transmitted helminth infections, uploated 2 March 2020. Diakses pada tanggal 07 November 2020.

[2] CDC. (2020). Paracites ascariasis (online) https://www.cdc.gov/parasites/ascari asis/index.html. Diakses pada tanggal 07 November 2020.

[3] Katzung, B. G. (1998). Farmakologi Dasar dan Klinik. Jakarta: EGC

[4] Asmah. N, Halimatussakdiah dan Ulil Amna. (2020). Analisa Kandungan Senyawa Metabolit Sekunder Ekstrak Daun Ketepeng Cina (Cassiaalata L.)dari Bireum Bayeun, Aceh Timur 
Quimica: Jurnal Kimia Sains dan Terapan ISSN 2716-0963 Volume 2, Nomor 2 e-ISSN 2716-1218

[5] Shargel L, and $Y u$ ABC. (1988). Biofarmasetika dan Farmakokinetika Terapan. Edisi Kedua. Diterjemahkan oleh Fasich dan Siti Sjamsiah. Surabaya: Airlangga University Press.

[6] I.O. Ademola 1, and J.N. Eloff. (2011). Ovicidal and larvicidal activity of Cassia alata leaf acetone extract and fractions on Haemonchus contortus: In vitro studies, Pharmaceutical Biology, 2011; 49(5): 539-544 (C) 2011 Informa Healthcare USA, Inc. ISSN 1388-0209 print/ISSN 1744-5116 online DOI: 10.3109/13880209.2010.526948

[7] Iman, F., Waluyo, J., dan Asyiah, I.N. (2015). Pengaruh Variasi Konsentrasi ekstrak Daun Ketepeng Cina (Cassia alata L.) Terhadap Mortalitas Cacing Ascaris suum Dewasa Secara In Vitro. repository.unej.ac.id

[8] Intannia, D., Amelia, R., dan Santoso, H. B. (2015). Pengaruh Pemberian Ekstrak Etanol dan Ekstrak n-Heksan Daun Ketepeng Cina (Cassia Alata. L) terhadap Waktu Kematian Cacing Pita Ayam (Raillietina Sp.) Secara In Vitro. Jurnal Pharmascience.

[9] Kuntari, T. (2008). Daya Antihelmintik Air Rebusan Daun Ketepeng Cina (Cassia alata L.) Terhadap Cacing Tambang Anjing In Vitro. Jurnal Logika

[10] Sherman IG, and Sherman VG. (1988). The Invertebrates Function and Form. New York; MacMillan Publishing Co. Inc

[11] Harborne. (1987). Metode Fitokimia, Penuntun Cara Modern Menganalisis Tumbuhan. Terjemahan: K. Padmawinata, I. Sudiro. Bandung: Institut Teknologi Bandung
[1 2] Molan, A. L., G. C. Waghorn, B. R. Min, and W. C. McNabb. (2000). The effect of condensed tanin from seven herbages on Trichostrongylus colubriformis larval migration in vitro. Folia Parasitol. 47:39-44.

[13] Tiwow, D. 2013. Uji Efek Antihelmintik Ekstrak Etanol Biji Pinang (Areca catechu) Terhadap Cacing Ascaris lumbricoides dan Ascaridia galli Secara In Vitro. PHARMACON Jurnal Ilmiah Farmasi - UNSRAT Vol. 2 No. 02

[14] Kalma. (2018). Studi kadar C-Reaktive Protein (CRP) Pada Penderita Diabetes Melitus Tipe 2. Jurnal Media Analis Kesehatan

[15] Musa, F. F. (2014). Uji Efektifitas Antelmintik Ekstrak Etanol Daun Ketepeng Cina (Cassia alata L.) Terhadap Cacing Gelang Ascaris lumbricoides. Jurnal Pharmascience.

[16] Bora, A. M., dan Samsuri. (2014). Vermisidal Dan Ovisidal Ekstrak Daun Pepaya Terhadap Cacing Ascaris suum Secara In Vitro. Jurnal Indonesia Medicus Veterinus.

[17] Soedarto. (2016). Buku Ajar Parasitologi Kedokteran. Jakarta: Sagung Seto. 